\title{
Isolation and characterization of a new CO-utilizing strain, Thermoanaerobacter thermohydrosulfuricus subsp. carboxydovorans, isolated from a geothermal spring in Turkey
}

\author{
Melike Balk • Hans G. H. J. Heilig • Miriam H. A. van Eekert • \\ Alfons J. M. Stams · Irene C. Rijpstra · Jaap S. Sinninghe-Damsté • \\ Willem M. de Vos $\cdot$ Servé W. M. Kengen
}

Received: 19 April 2009/Accepted: 3 August 2009/Published online: 23 August 2009

(C) The Author(s) 2009. This article is published with open access at Springerlink.com

\begin{abstract}
A novel anaerobic, thermophilic, Gram-positive, spore-forming, and sugar-fermenting bacterium (strain TLO) was isolated from a geothermal spring in Ayaş, Turkey. The cells were straight to curved rods, $0.4-0.6 \mu \mathrm{m}$ in diameter and 3.5-10 $\mu \mathrm{m}$ in length. Spores were terminal and round. The temperature range for growth was $40-80^{\circ} \mathrm{C}$, with an optimum at $70^{\circ} \mathrm{C}$. The $\mathrm{pH}$ optimum was between 6.3 and 6.8. Strain TLO has the capability to ferment a wide variety of mono-, di-, and polysaccharides and proteinaceous substrates, producing mainly lactate, next to acetate, ethanol, alanine, $\mathrm{H}_{2}$, and $\mathrm{CO}_{2}$. Remarkably, the bacterium was able to grow in an atmosphere of up to $25 \%$ of $\mathrm{CO}$ as sole electron donor. $\mathrm{CO}$ oxidation was coupled to $\mathrm{H}_{2}$ and $\mathrm{CO}_{2}$ formation. The $\mathrm{G}+\mathrm{C}$ content of the genomic DNA was $35.1 \mathrm{~mol} \%$. Based on 16S rRNA gene sequence analysis and the DNA-DNA hybridization data, this bacterium
\end{abstract}

Communicated by F. Robb.

The GenBank accession number for the 16S rRNA sequence of Thermoanaerobacter sp. is AY 328919.

M. Balk · H. G. H. J. Heilig - M. H. A. van Eekert . A. J. M. Stams · W. M. de Vos · S. W. M. Kengen Laboratory of Microbiology, Wageningen University, Dreijenplein 10, 6703 HB Wageningen, The Netherlands

I. C. Rijpstra · J. S. Sinninghe-Damsté

Department of Marine Organic Biogeochemistry, NIOZ Royal Netherlands Institute for Sea Research, P.O. Box 59, 1790 AB Den Burg, Texel, The Netherlands

Present Address:

M. Balk ( $\square)$

Netherlands Institute of Ecology (NIOO-KNAW),

Centre for Limnology, Rijksstraatweg 6,

3631 AC Nieuwersluis, The Netherlands

e-mail: M.Balk@nioo.knaw.nl is most closely related to Thermoanaerobacter thermohydrosulfuricus and Thermoanaerobacter siderophilus (99\% similarity for both). However, strain TLO differs from Thermoanaerobacter thermohydrosulfuricus in important aspects, such as CO-utilization and lipid composition. These differences led us to propose that strain TLO represents a subspecies of Thermoanaerobacter thermohydrosulfuricus, and we therefore name it Thermoanaerobacter thermohydrosulfuricus subsp. carboxydovorans.

Keywords Thermoanaerobacter sp. - Geothermal springs - Thermophiles · Bacteria - Thermoanaerobacter

\section{Introduction}

Diverse thermophilic heterotrophic anaerobes have been isolated from a variety of habitats. Members of the genus Thermoanaerobacter, in the order Thermoanaerobacteriales, are widely distributed in hydrothermal and oilproducing vents, volcanic hot springs, non-volcanic geothermally heated subsurface aquifers, soil, sugar beet, and sugar cane extraction juices (Klaushofer and Parkkinen 1965; Wiegel and Ljungdahl 1981; Schmid et al. 1986; Cayol et al. 1995; Cook et al. 1996; Kozianowski et al. 1997; Larsen et al. 1997; Slobodkin et al. 1999; Fardeau et al. 2000; Kim et al. 2001; Onyenwoke et al. 2007; Wagner et al. 2008). Thermoanaerobacter species are strictly anaerobic, thermophilic, rod-shaped bacteria, growing between 55 and $75^{\circ} \mathrm{C}$, and most of them form round to oval terminal spores. Thermoanaerobacter species have been investigated for their sensitivity to different antibiotics but no differences have been found. A wide range of carbohydrates can be utilized by this group of organisms. Although the end products are mainly acetate, 
lactate, ethanol, $\mathrm{H}_{2}$, and $\mathrm{CO}_{2}$, the most abundant end product depends on the species and the growth conditions. Generally, thiosulfate can be used as electron acceptor in anaerobic respiration. Here we describe a new anaerobic thermophilic bacterium which belongs to the genus Thermoanaerobacter, and which differs from its closest relatives with respect to CO-utilization, lipid composition and fermentation pattern.

\section{Materials and methods}

\section{Collection of the sample}

Strain TLO was enriched from a mud sample obtained from a geothermal spring in Ayaş in Turkey. The geographical coordinates of the sampling site were $40.2^{\circ}$ latitude, $32.4^{\circ}$ longitude. The temperature and the $\mathrm{pH}$ of the sampling site was $75^{\circ} \mathrm{C}$ and 7.5 (at $75^{\circ} \mathrm{C}$ ), respectively.

\section{Isolation}

The mud sample $(5 \mathrm{ml})$ was directly transferred to $50-\mathrm{ml}$ sterilized bicarbonate-buffered medium in a $117-\mathrm{ml}$ serum vial sealed with a butyl rubber stopper under a gas phase of $\mathrm{N}_{2} / \mathrm{CO}_{2}(80 / 20, \mathrm{v} / \mathrm{v})$. Cellobiose $(20 \mathrm{mM})$ was used as electron donor. The enrichment culture was grown at $68^{\circ} \mathrm{C}$ and after growth, contained predominantly spore-forming rods. Isolation of the dominant bacterium was achieved by the soft-agar dilution method. The colonies, visible after three days of incubation, were uniformly round, 0.5$1.0 \mathrm{~mm}$ in diameter and white. They were picked from the highest dilution $\left(10^{-8}\right)$ with a sterile needle and subcultured in liquid medium containing $20 \mathrm{mM}$ of cellobiose as a substrate. Serial agar and liquid dilutions in cellobiosecontaining media were repeated until a pure culture was obtained. The pure culture was designated strain TLO (=DSM15750, =ATCC BAA-892).

\section{Media and cultivation}

The composition of the BM medium used for routine growth and substrate utilization experiments were based on medium 120 of the DSMZ (http://www.dsmz.de), with the following modifications: casitone, methanol and cysteine$\mathrm{HCl}$ were omitted and the amount of yeast extract was either lowered to $0.25 \mathrm{~g} \mathrm{l}^{-1}$ or not added for growth experiments. Routinely, cellobiose $(20 \mathrm{mM})$ was used as the carbon and energy source. The $\mathrm{pH}$ of the medium (standard $\mathrm{pH}$ was 6.7) was adjusted using temperature corrected $\mathrm{pH}$ standards and by injecting calculated amounts of sterile $\mathrm{Na}_{2} \mathrm{CO}_{3} / \mathrm{NaHCO}_{3}$ or $\mathrm{HCl}$ from the sterile, anaerobic stock solutions. The medium was boiled and cooled to room temperature under a stream of $\mathrm{O}_{2}$-free $\mathrm{N}_{2}$ gas. The medium was anaerobically dispensed into serum bottles under a $\mathrm{N}_{2} / \mathrm{CO}_{2}(80 / 20$, v/v) gas atmosphere. The bottles were closed with butyl rubber stoppers sealed with crimp seals. The medium was autoclaved for $20 \mathrm{~min}$ at $121^{\circ} \mathrm{C}$. Prior to inoculation, the medium was reduced with sterile stock solutions of $\mathrm{Na}_{2} \mathrm{~S}, 7-9 \mathrm{H}_{2} \mathrm{O}$ and $\mathrm{NaHCO}_{3}$ to obtain final concentrations of 0.04 and $0.2 \%$, respectively.

The pure culture of strain TLO was either maintained by weekly transfer of a $1 \%(\mathrm{v} / \mathrm{v})$ inoculum to fresh medium or inoculated from frozen glycerol stocks. Bottles were incubated in the dark without shaking. To investigate and optimize lactate production, some experiments were performed with phosphate-buffered medium 640 of the DSMZ ( $\mathrm{PB}$ medium), which enabled a lower $\mathrm{pH}$ between 4.0 and 6.7. The reference strains used in this study were Thermoanaerobacter siderophilus (DSM 12299) (Slobodkin et al. 1999) and T. thermohydrosulfuricus (DSM 567) (Klaushofer and Parkkinen 1965).

Growth on different substrates was measured as the optical density at $600 \mathrm{~nm}$ (OD600).

Uninoculated medium served as a reference. The results represent duplicate experiments. The optimal growth temperature was determined by following growth at various temperatures between $35^{\circ}$ and $85^{\circ} \mathrm{C}$, with 5-degree intervals.

Preparation of cell-free extract and enzyme measurement

Cell extracts used for enzyme assays were obtained from cells grown in the PB medium supplemented with $25 \%$ of $\mathrm{CO}$ as electron donor. The preparation of cell extracts was performed under anoxic conditions in an anaerobic glove box. Cells were collected by centrifugation at $10,000 \mathrm{~g}$ for $10 \mathrm{~min}$ at $4^{\circ} \mathrm{C}$. The cell pellet was suspended $(1: 2[\mathrm{w} / \mathrm{v}])$ in $15 \mathrm{mM}$ potassium/sodium phosphate buffer, $\mathrm{pH}$ 7.2. The cells were disrupted by ultrasonic disintegration (Sonics \& Materials Inc., Danbury, Conn.) at $40 \mathrm{Kc} / \mathrm{s}$ for $30 \mathrm{~s}$ followed by cooling for $30 \mathrm{~s}$ on ice. The cycle was repeated four times. Cell debris and whole cells were removed by centrifugation at $13,000 \mathrm{~g}$ for $10 \mathrm{~min}$ at $4^{\circ} \mathrm{C}$. The supernatant was used for enzyme assays. Carbon monoxide dehydrogenase $(\mathrm{CODH})$ activity was assayed at the temperatures between 60 and $80^{\circ} \mathrm{C}$ by following the COdependent reduction of oxidized methyl viologen (MV) as described by Svetlitchnyi et al. (2001). One unit of CO oxidation activity was defined as the amount of enzyme that catalyzes the reduction of $2 \mu \mathrm{mol}$ of $\mathrm{MV} \mathrm{min}^{-1}$, which is equivalent to $1 \mu \mathrm{mol}$ of $\mathrm{CO}$ oxidized $\mathrm{min}^{-1}$. The protein content of the cell extracts was determined according to the method of Bradford (1976) with bovine serum albumin as a standard. 
Substrates and electron acceptors utilization tests

The ability of strain TLO to metabolize substrates was tested in the bicarbonate-buffered medium (BM). Substrates were added from sterile, anoxic concentrated stock solutions to final concentrations of $20 \mathrm{mM}$, unless otherwise indicated. To test the use of potential electron acceptors with glucose as electron donor, thiosulfate $(20 \mathrm{mM})$, elemental sulfur $(2 \%, \mathrm{w} / \mathrm{v})$, sodium sulfite $(5 \mathrm{mM}), \mathrm{FeCl}_{3}(10 \mathrm{mM}), \mathrm{Fe}(\mathrm{III})-\mathrm{NTA}(10 \mathrm{mM}), \mathrm{Fe}(\mathrm{III})-$ citrate $(10 \mathrm{mM}), \mathrm{MnO}_{2}(5 \mathrm{mM})$, anthraquinone-2,6-disulfonate (AQDS) $(20 \mathrm{mM})$ and arsenate $(10 \mathrm{mM})$, sulfate $(20 \mathrm{mM})$, nitrate $(20 \mathrm{mM})$ or selenate $(10 \mathrm{mM})$ was added to the medium at the indicated concentrations. The use of the electron acceptors was examined by following the optical density $(600 \mathrm{~nm})$ of the culture, detection of sulfide production (for sulfate, thiosulfate, sulfite and elemental sulfur), change of visible color (for AQDS) and measurements of the reduction of $\mathrm{Fe}$ (III) or formation of a precipitate (for $\mathrm{MnO}_{2}$ ) in the medium.

To test the utilization of $\mathrm{CO}$, the bacterium was grown in $117-\mathrm{ml}$ serum vials that contained $50 \mathrm{ml}$ of the PB medium and that were sealed with butyl rubber stoppers and aluminum caps. These vials with $50 \mathrm{ml}$ of the $\mathrm{PB}$ medium were flushed with $\mathrm{N}_{2}$. The PB medium was supplemented with $0.2 \mathrm{~g}$ yeast extract $1^{-1}$ and trypticase was omitted. Before addition of $\mathrm{CO}$, an underpressure $(0.2 \mathrm{bar})$ was created in the vials and $\mathrm{CO}$ was added to give a volume percentage (vol\%) in the gas phase of 0 to $60 \mathrm{vol} \%$. Then, $\mathrm{N}_{2}$ was added to a pressure of $120 \mathrm{kPa}(100 \mathrm{kPa}=1 \mathrm{bar})$. The culture was incubated at $65^{\circ} \mathrm{C}$ and shaken at $100 \mathrm{rpm}$. The measurements represent four replicates for each duplicate culture grown at the indicated temperature.
Phylogeny, DNA base composition and DNA reassociation

DNA was extracted and purified using the UltraClean Soil DNA kit (MoBio). PCR was performed with the bacterial primers 7f and 1510r (Lane 1991) by using the Taq DNA polymerase kit (Life Technologies) to amplify the bacterial 16S rRNA gene. The PCR products were purified with the Qiaquick PCR purification kit (Qiagen, Hilden, Germany) according to the manufacturer's instructions. Sequencing of the complete 16S rRNA gene was performed at Westburg Genomics (http://genomics.westburg.nl). A total of 1,676 nucleotides of the 16S rRNA gene were sequenced. The sequences were checked with the alignment programs of the ARB package (Ludwig et al. 2004), and a rooted neighbor-joining tree (Escherichia coli 8, D83536 positions 38-1449) was constructed using Moorella thermoacetica as an outgroup species (Fig. 1). On-line similarity analysis of the $16 \mathrm{~S}$ rRNA gene sequences was performed with the BLAST program at NCBI and EMBL databases.

The $\mathrm{G}+\mathrm{C}$ content determination and the DNA-DNA hybridizations were performed at the DSMZ (Braunschweig, Germany). DNA was isolated and purified by chromatography on hydroxyapatite (Cashion et al. 1977) and the $\mathrm{G}+\mathrm{C}$ content of strain TLO was determined using the HPLC method described by Mesbah et al. (1989); unmethylated lambda DNA (Sigma) was used as the standard. DNA-DNA hybridization was carried out as described by De Ley et al. (1970), with the modifications described by Huss et al. (1983) and Escara and Hutton (1980), using a model 2600 spectrophotometer equipped with a model 2527-R thermoprogrammer and plotter (Gilford Instrument
Fig. 1 Dendrogram showing the position of strain TLO among the members of the order Thermoanaerobacteriales and related bacteria. Phylogenetic analysis based on 16S rRNA gene sequences available from GenBank data bases (accession numbers are given in parentheses). The neighborjoining tree was reconstructed from distance matrices; bootstrap values $(1000$ replication) greater than $50 \%$ are listed at branching points. Bar evolutionary distance of 0.10

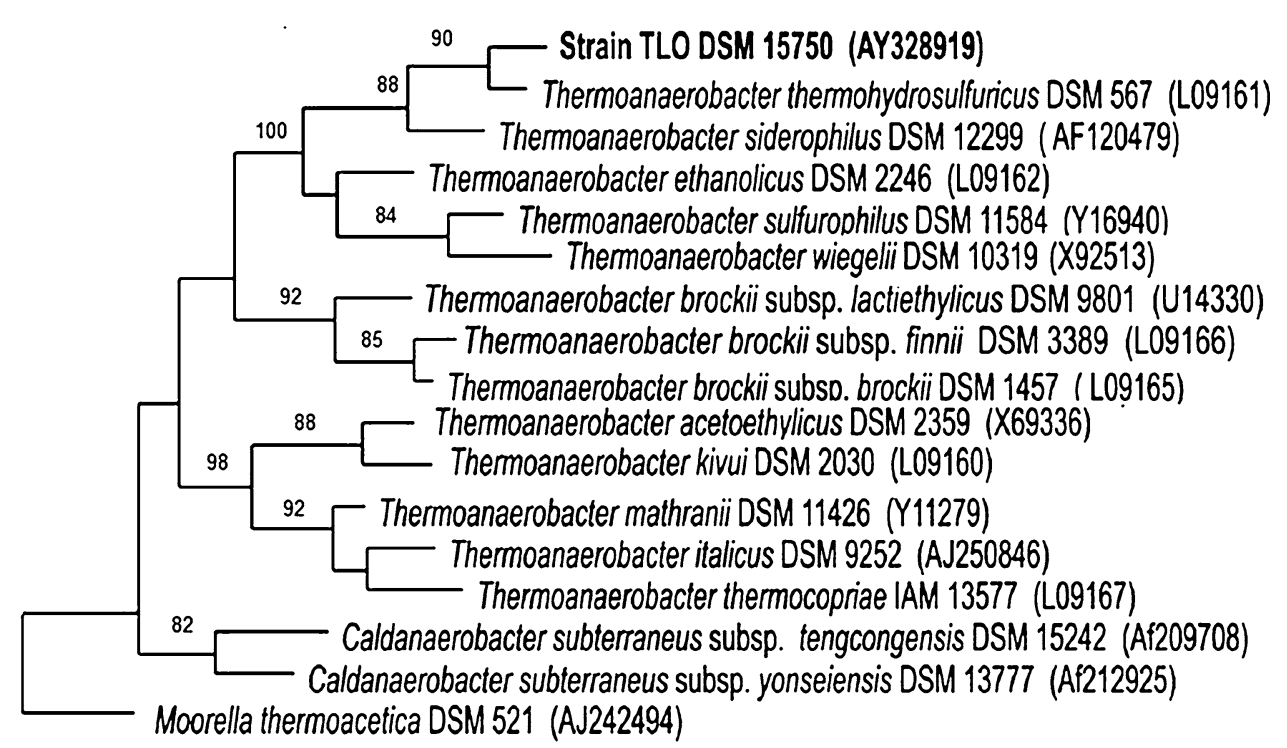

0.10 
Laboratories). Renaturation rates were computed with the TRANSFER.BAS program (Jahnke 1992).

Lipid analysis

Bacterial cultures of strain TLO, T. thermohydrosulfuricus and $T$. siderophilus grown on glucose in the BM medium were harvested by centrifugation $\left(14,500 \mathrm{~g}, 20 \mathrm{~min}, 4^{\circ} \mathrm{C}\right)$ and pellets were washed with distilled water. Lipids from lyophilized cells were extracted ultrasonically using a mixture of dichloromethane (DCM):methanol of 2:1 (v/v) and this procedure was repeated four times. The residue was saponified with $1 \mathrm{~N} \mathrm{KOH}$ in $96 \%$ of methanol by refluxing for $1 \mathrm{~h}$ and subsequently neutralized and extracted with DCM. After addition of internal standards, the "free" and "bound" lipid extracts were methylated and silylated and subsequently analyzed by GC and GC-mass spectrometry (GC-MS).

\section{Analytical methods}

Most substrates were measured by HPLC as described previously by Stams et al. (1993). Gases and alcohols were measured by gas chromatography (Balk et al. 2003; Henstra and Stams 2004) and thiosulfate, nitrate and sulfate were analyzed by a HPLC system equipped with an Ionpac AS9-SC column and an ED 40 electrochemical detector (Dionex, Sunnyvale, CA) (Scholten and Stams 1995). Sulfide was analyzed by the method of Trüper and Schlegel (1964). Fe(III) reduction was determined by analyzing Fe(II) with the ferrozine method according to (Lovley and Phillips 1988).

To determine whether D- or L-lactic acid was produced, an enzymatic test kit (Enzytec, Scil Diagnostics GmbH) was used which involved D- or L-lactate dehydrogenase as the discriminating enzyme (From chicken heart, Sigma).

\section{Results}

\section{Morphology}

Cells of strain TLO were straight to slightly curved rods, $0.4-0.6 \mu \mathrm{m}$ in diameter and 3.5-10 $\mu \mathrm{m}$ in length depending on the growth phase (Fig. 2a). The cells stained Grampositive (Murray et al. 1994), occurred singly, in pairs or in long chains. Spores were terminal, round, heat resistant endospores. In the presence of thiosulfate and at acidic $\mathrm{pH}$ values, elemental sulfur was deposited inside the cells, which was visible as bright deposits under phase-contrast microscopy (Fig. 2b). Spores were usually found during the late exponential or early stationary growth phase in liquid cultures.
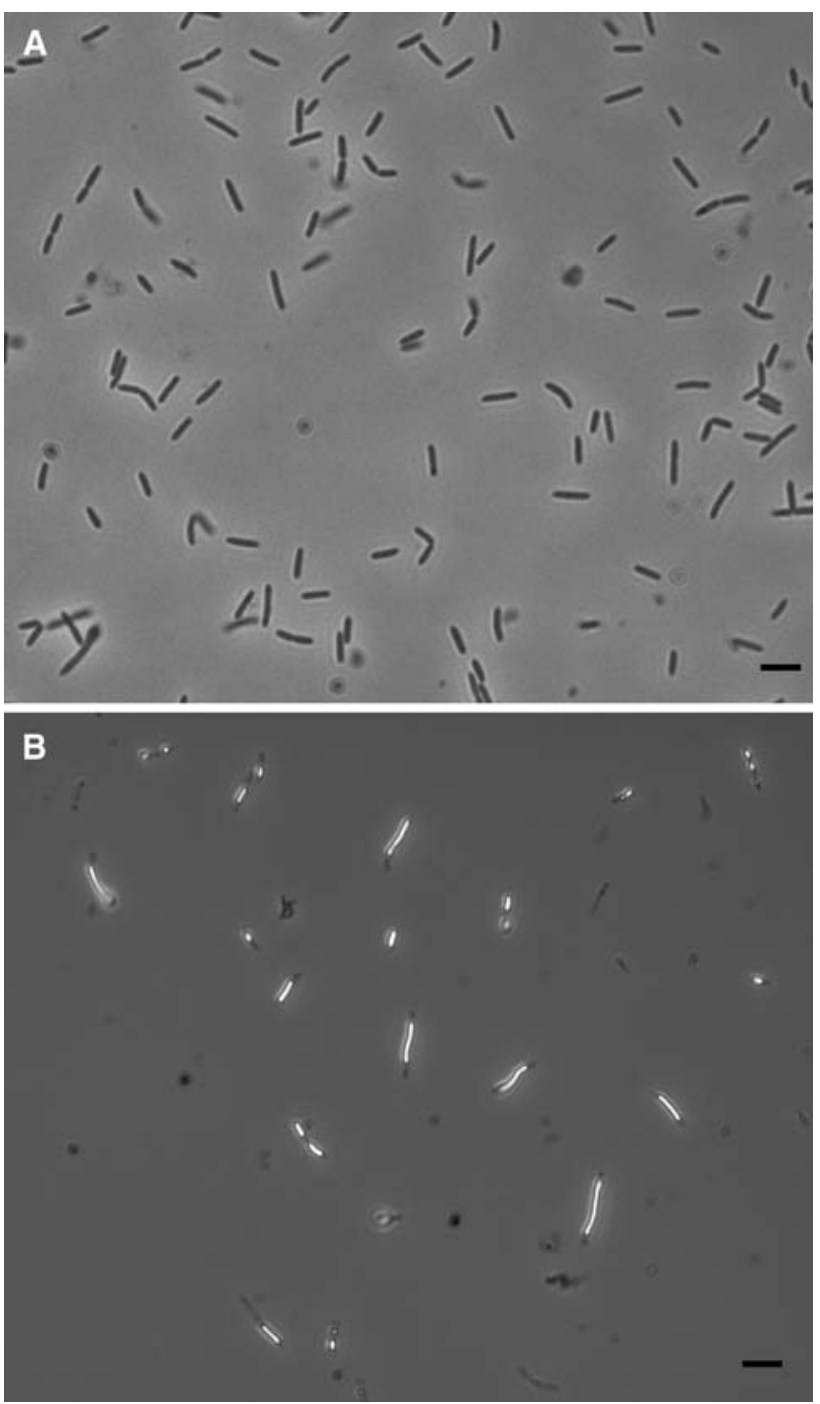

Fig. 2 Phase-contrast micrograph of strain TLO (a). Elemental sulfur deposits in thiosulfate supplemented medium (b). Bar $2.5 \mu \mathrm{m}$

pH-, temperature-, and sodium chloride concentration ranges for growth

The $\mathrm{pH}$ of the medium was adjusted using temperature corrected $\mathrm{pH}$ standards and by injecting calculated amounts of sterile $\mathrm{Na}_{2} \mathrm{CO}_{3} / \mathrm{NaHCO}_{3}$ or $\mathrm{HCl}$ from the sterile, anaerobic stock solutions. The effects of the $\mathrm{pH}$ and $\mathrm{NaCl}$ concentration were determined at the optimal temperature for growth. Under these conditions, strain TLO grew between $40^{\circ} \mathrm{C}$ and $80^{\circ} \mathrm{C}$ with optimum growth around $70^{\circ} \mathrm{C}$, while no growth was detected at $35^{\circ} \mathrm{C}$ and $85^{\circ} \mathrm{C}$. Growth was observed between $\mathrm{pH} 4.5$ and 9, with optimum growth around $\mathrm{pH} 6.5$ (pH 6.36.5). Growth occurred at $\mathrm{NaCl}$ concentrations ranging from 0 to $20 \mathrm{~g} \mathrm{l}^{-1}$, with optimum growth at $5 \mathrm{~g}$ $\mathrm{NaCl}^{-1}$. No growth was observed at $30 \mathrm{~g} \mathrm{l}^{-1}$. Under 
the optimal conditions of growth and in the presence of thiosulfate $(20 \mathrm{mM})$, the doubling time of the isolate was about $70 \mathrm{~min}$ and the cell density $\left(\mathrm{OD}_{600}\right)$ reached 0.8 .

Growth substrates and products

Strain TLO grew on the following substrates (at a concentration of $20 \mathrm{mM}$ unless indicated otherwise) in the presence or absence of thiosulfate as the electron acceptor: yeast extract, peptone, beef extract, fructose, glucose, galactose, lactose, maltose, mannose, ribose, sucrose, xylose, xylan, starch, pectin, inulin, and cellobiose. Slow growth was also observed on mannitol and carboxymethylcellulose (CMC). No growth occurred with formate, acetate, lactate, methanol, ethanol, propanol, butanol, propionate, succinate, malate, glycine, alanine, arginine, cellulose, and lichenan.

Under standard conditions at $\mathrm{pH} 6.7$, lactate was the major end product of sugar fermentation (in the absence of thiosulfate), but acetate, ethanol, alanine, $\mathrm{H}_{2}$, and $\mathrm{CO}_{2}$ were formed as well, although in minor amounts. This metabolic profile was largely influenced by the growth conditions. At more acidic $\mathrm{pH}$ values, lactate production increased, and when the $\mathrm{pH}$ of the medium was between 4.5 and 5.0 around $1.7 \mathrm{~mol}$ lactate and $0.1 \mathrm{~mol}$ ethanol were produced per mol glucose fermented and acetate could not be detected. Increasing the $\mathrm{pH}$ up to 9.0 resulted in more acetate $(1.6 \mathrm{~mol} / \mathrm{mol}$ glucose $)$ and less lactate $(0.4 \mathrm{~mol} / \mathrm{mol}$ glucose $)$. Thiosulfate utilization also affected the metabolic patterns during sugar utilization. In the absence of thiosulfate, per mol of glucose $1.2 \mathrm{~mol}$ of lactate, $0.3 \mathrm{~mol}$ of acetate, $0.4 \mathrm{~mol}$ of ethanol, $0.3 \mathrm{~mol}$ of alanine, $0.2 \mathrm{~mol}$ of hydrogen, and $0.7 \mathrm{~mol}$ of $\mathrm{CO}_{2}$ were produced. In the presence of thiosulfate, the product formation from glucose of the strain changed with an increase in acetate production and a decrease in alanine production. Around $1.3 \mathrm{~mol}$ of acetate was produced per mol glucose fermented, and the other products were lactate $(0.6 \mathrm{~mol})$, ethanol $(0.2 \mathrm{~mol})$, alanine $(0.02 \mathrm{~mol})$, hydrogen $(0.03 \mathrm{~mol})$, and $\mathrm{CO}_{2}(1.5 \mathrm{~mol})$. Under these conditions $1 \mathrm{~mol}$ of thiosulfate was reduced to $2 \mathrm{~mol}$ of sulfide. Remarkably, when the phosphate-buffered and $\mathrm{N}_{2}$-flushed medium (PB medium; $\mathrm{pH}$ 5.8) was used, thiosulfate was converted to elemental sulfur instead of sulfide as in the BM medium.

Strain TLO was also found to grow in an atmosphere of up to $25 \%$ of $\mathrm{CO}$ as a sole electron donor. The bacterium either did not grow or did not completely oxidize $\mathrm{CO}$ at higher concentrations than $25 \%$ of $\mathrm{CO}$ in the gas phase. The complete conversion of $\mathrm{CO}$ was only observed in the bottles with $\mathrm{CO}$ up to $25 \%$.

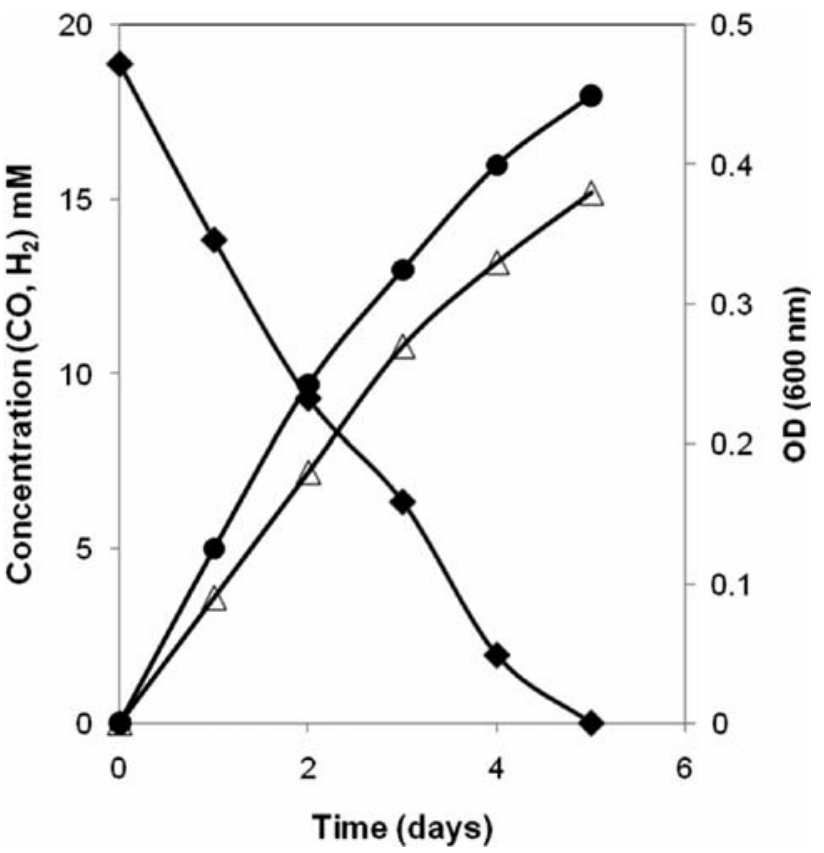

Fig. $3 \mathrm{CO}$ conversion by strain TLO performed at $65^{\circ} \mathrm{C}$ and shaken at $100 \mathrm{rpm}$ with $\mathrm{CO}$ as sole substrate. The results represent the average of duplicate experiments. Carbon monoxide (filled diamond), hydrogen (filled circle) and OD (open triangle)

CO oxidation was coupled to $\mathrm{H}_{2}$ and $\mathrm{CO}_{2}$ formation (Fig. 3). In agreement with the observed CO-utilization, cell-free extracts were shown to exhibit $\mathrm{CODH}$ activity.

The maximum $\mathrm{CODH}$ activity in cell-free extracts at 60 , $65,70,75$, and $80^{\circ} \mathrm{C}$ was found to be $66 \pm 4.7,72 \pm 3.9$, $46 \pm 2.9,12 \pm 2.1$, and $2.2 \pm 0.17 \mathrm{U} \mathrm{mg}$ of protein $^{-1}$, respectively.

\section{Electron acceptors}

In addition to thiosulfate $(20 \mathrm{mM})$, elemental sulfur ( $2 \%$, w/v), sodium sulfite $(5 \mathrm{mM}), \mathrm{FeCl}_{3}(10 \mathrm{mM}), \mathrm{Fe}(\mathrm{III})$-NTA $(10 \mathrm{mM}), \mathrm{Fe}(\mathrm{III})$-citrate $(10 \mathrm{mM}), \mathrm{MnO}_{2}(5 \mathrm{mM})$, anthraquinone-2,6-disulfonate (AQDS) $(20 \mathrm{mM})$, and arsenate $(10 \mathrm{mM})$ could serve as electron acceptors. Sulfate $(20 \mathrm{mM})$, nitrate $(20 \mathrm{mM})$, and selenate $(10 \mathrm{mM})$ could not be utilized.

\section{Yeast extract dependence}

Yeast extract did affect product formation. When the yeast extract concentration was raised to $0.1 \%$ or higher, glucose fermentation was shifted from lactate and ethanol to more lactate and acetate formation.

Lactate produced from glucose, fructose, or maltose was mostly L-lactate with a content of more than $99 \%$ based on total lactic acid produced. 
Antibiotic susceptibility

Penicillin, ampicillin, streptomycin, and novobiocin at $100 \mu \mathrm{g} \mathrm{ml}^{-1}$ did not inhibit growth. However, chloramphenicol, neomycin, and kanamycin completely inhibited growth at concentrations of $100 \mu \mathrm{g} \mathrm{ml}^{-1}$ medium.

DNA base composition

The $\mathrm{G}+\mathrm{C}$ content of the DNA of strain TLO was found to be $35.1 \mathrm{~mol} \%$.

\section{Phylogeny and DNA reassociation}

A total of 1,676 nucleotides of the 16S rRNA gene of strain TLO were sequenced from and compared with the members of the genus Thermoanaerobacter and related organisms. The closest phylogenetic relatives of strain TLO were T. siderophilus and T. thermohydrosulfuricus (formerly Clostridium thermohydrosulfuricum, Lee et al. 1993) (similarity of 99\% for both) (Fig. 1).

DNA-DNA hybridization values (all in duplicate) between strain TLO and the two bacteria, T. siderophilus and T. thermohydrosulfuricus, were between $37 \%$ and $45 \%$, and $72 \%$ and $76 \%$, respectively.

\section{Lipid composition}

The most abundant fatty acids of strain TLO, T. thermohydrosulfuricus and T. siderophilus were iso- $\mathrm{C}_{15: 0}$ and iso- $\mathrm{C}_{17: 0}$. Table 2 shows the lipid composition of strain TLO in comparison with phylogenetically closely related species.

\section{Discussion}

Here we describe the characterization of a novel thermophilic, Gram-positive, anaerobic bacterium, which was isolated from a geothermal spring in Ayaş in Turkey. Based on the 16SrRNA sequence, strain TLO is phylogenetically closely related to T. thermohydrosulfuricus and T. siderophilus (Fig. 1), although its $\mathrm{G}+\mathrm{C}$ content of $35.1 \mathrm{~mol} \%$ is different from that of T. hydrosulfuricus (37.6\%) and T. siderophilus (32.0\%). Strain TLO shares several phenotypic features with its close relatives, like a broad substrate specificity, optimal $\mathrm{pH}$ - and T-range and the facultative use of thiosulfate.

However, several obvious differences were found as well (Table 1). First, in contrast to the type strain T. thermohydrosulfuricus and also T. siderophilus, strain TLO is able to use $\mathrm{CO}$ as electron donor, which is converted to $\mathrm{H}_{2}$ and $\mathrm{CO}_{2}$. This feature is not new among Gram-positive anaerobes, and various recently isolated thermophiles have been shown to grow chemolithoautotrophically through the conversion of $\mathrm{CO}+\mathrm{H}_{2} \mathrm{O}$ to $\mathrm{H}_{2}+\mathrm{CO}_{2}$ (Svetlichnyi et al. 1994, 2001; Sokolova et al. 2001, 2002, 2004, 2005, 2007; Slepova et al. 2006). Utilization of $\mathrm{CO}$ has also been demonstrated for several representatives of a subdivision of the Thermoanaerobacter genus (Group 3) (Subbotina et al. 2003),
Table 1 Phenotypic characteristics of strain TLO in comparison with phylogenetically closely related species

Data for reference species were obtained from Klaushofer and Parkkinen (1965) and Slobodkin et al. (1999)

$N R$ not reported, $V$ variable, $W$ weak

${ }^{\mathrm{a}}$ Tested in this report; ${ }^{\mathrm{b}}$ Data from Gavrilov et al. (2003)

\begin{tabular}{llll}
\hline Feature & Strain TLO & T. thermohydrosulfuricus & T. siderophilus \\
\hline Source & Geothermal spring & $\begin{array}{c}\text { Extraction juices of } \\
\text { beet sugar factory }\end{array}$ & Hydrothermal vent \\
Gram reaction & + & $\mathrm{V}$ & + \\
Spores & + & + & + \\
Temperature range $\left({ }^{\circ} \mathrm{C}\right)$ & $40-80$ & $40-78$ & $39-78$ \\
Optimum temperature $\left({ }^{\circ} \mathrm{C}\right)$ & $68-70$ & $65-68$ & $69-71$ \\
pH range & $4.5-9$ & $5-9$ & $4.8-8.2$ \\
Optimum pH & $6.3-6.8$ & $6.9-7.5$ & $6.3-6.5$ \\
DNA G $+\mathrm{C}$ content $(\mathrm{mol} \%)$ & 35.1 & 37.6 & 32 \\
Reduction of arsenate & + & $+^{\mathrm{a}}$ & $+{ }^{\mathrm{a}}$ \\
Growth substrates & & & $\mathrm{NR}$ \\
Ribose & + & + & $\mathrm{V}$ \\
Mannitol & $\mathrm{W}$ & $\mathrm{W}$ & + \\
Starch & + & + & $\mathrm{NR}$ \\
Pectin & + & + & - \\
Xylan & + & + & - \\
Carboxymethylcellulose & $\mathrm{W}$ & + & $-{ }^{\mathrm{b}}$ \\
CO $($ up to $25 \%$ v/v) & + & $-{ }^{\mathrm{a}}$ & \\
\hline
\end{tabular}


Table 2 Lipid composition (in \% of total quantified lipids) of strain TLO in comparison with phylogenetically closely related species

\begin{tabular}{|c|c|c|c|c|c|c|}
\hline \multirow[t]{2}{*}{ Lipids } & \multicolumn{2}{|c|}{ Strain TLO } & \multicolumn{2}{|c|}{ T. thermohydrosulfuricus } & \multicolumn{2}{|c|}{ T. siderophilus } \\
\hline & FLF & BLF & FLF & BLF & FLF & BLF \\
\hline Summed concentration (mg/g dry weight) & 6.7 & 2.0 & 17.4 & 2.9 & 8.6 & 0.6 \\
\hline$n-\mathrm{C}_{14} \mathrm{FA}$ & 4 & 1 & n.d. & n.d. & 7 & 2 \\
\hline Iso- $\mathrm{C}_{15} \mathrm{FA}$ & 39 & 25 & 81 & 60 & 3 & 40 \\
\hline Anteiso- $\mathrm{C}_{15} \mathrm{FA}$ & 2 & 2 & 2 & 2 & 0 & 8 \\
\hline$n-\mathrm{C}_{16} \mathrm{FA}$ & 5 & 1 & 2 & 2 & 19 & 5 \\
\hline Iso- $\mathrm{C}_{17} \mathrm{FA}$ & 16 & 5 & 12 & 22 & 66 & 16 \\
\hline Anteiso- $\mathrm{C}_{17} \mathrm{FA}$ & 2 & 1 & 1 & 2 & 5 & 4 \\
\hline$n-\mathrm{C}_{18} \mathrm{FA}$ & n.d. & n.d. & n.d. & n.d. & n.d. & 1 \\
\hline Iso- $\mathrm{C}_{15}-\mathrm{OH}$ & 10 & n.d. & 1 & n.d. & $<1$ & 3 \\
\hline$n-\mathrm{C}_{16}-\mathrm{OH}$ & 7 & 1 & n.d. & n.d. & n.d. & 1 \\
\hline Iso- $\mathrm{C}_{17}-\mathrm{OH}$ & 9 & 9 & 1 & n.d. & n.d. & n.d. \\
\hline Anteiso- $\mathrm{C}_{17}-\mathrm{OH}$ & 4 & $<1$ & n.d. & n.d. & n.d. & n.d. \\
\hline$\alpha, \omega$-13,16-Dimethyl-octacosanedoic acid & 2 & 50 & n.d. & 12 & n.d. & 20 \\
\hline$\alpha, \omega$-13,16-Dimethyl-triacontanedioic acid & n.d. & 2 & n.d. & n.d. & n.d. & n.d. \\
\hline 30-Hydroxy-13,16-dimethyl-triacontanoic acid & n.d. & 3 & n.d. & n.d. & n.d. & n.d. \\
\hline
\end{tabular}

The strains were grown in glucose-containing bicarbonate-buffered (BM) medium at $65^{\circ} \mathrm{C}$ for $24 \mathrm{~h}$

n.d. not detected, $F A$ fatty acid, $O H$ alcohol, $F L F$ free lipid fraction, $B L F$ bound lipid fraction

which was recently reassigned to the genus Caldanaerobacter (Fardeau et al. 2004). For example, Caldanaerobacter subterraneus subsp. tengcongensis and C. subterraneus subsp. pacificius are able to use CO. However, among the more distantly related, true Thermoanaerobacter strains, CO-dehydrogenase activity has not been demonstrated or determined yet, with the exception of strain TLO, as shown here (Table 1). It is important to realize that the bacterium either did not grow or did not completely oxidize $\mathrm{CO}$ at concentrations higher than $25 \%$ (v/v) in the gas phase. Often, growth is only tested in the presence of $100 \% \mathrm{CO}$, which may be toxic and then gives rise to false conclusions regarding the ability to grow on $\mathrm{CO}$. Moreover, levels of $\mathrm{CO}$ in natural hot environments are probably much lower, and microorganisms growing on $\mathrm{CO}$ in such environments are likely to be able to use very low $\mathrm{CO}$ concentrations. For example, Carboxydothermus hydrogenoformans consumed $\mathrm{CO}$ to below detectable levels of $2 \mathrm{ppm}$, when the $\mathrm{CO}_{2}$ concentration was kept low (A.M. Henstra et al., unpublished data).

Second, significant differences in the lipid composition of strain TLO and the phylogenetically closely related species, T. thermohydrosulfuricus and T. siderophilus, were detected as shown in Table 2. In T. siderophilus the iso-C17 FA was substantially more abundant than in the TLO strain and T. thermohydrosulfuricus. Interestingly, in all three strains the uncommon membrane-spanning $\alpha, \omega$ 13,16-dimethyl-octacosanedioic acid, previously detected in the phylogenetically related T. ethanolicus (Jung et al. 1994; Lee et al. 2002) was present in substantial amounts, especially in strain TLO. Since increasing ethanol concentrations were found to be associated with high levels of $\mathrm{C}_{30}$ fatty acids in T. ethanolicus (Burdette et al. 2002), the high tolerance to ethanol further verifies also the potential of strain TLO.

Strain TLO showed some additional features that are noteworthy. The use of thiosulfate as terminal electron acceptor is a common property of many thermophilic fermentative bacteria. Both hydrogen sulfide and elemental sulfur have been reported as reduced end product. The formation of elemental sulfur deposits was observed for Thermoanaerobacter italicus (Kozianowski et al. 1997) and T. uzonensis (Wagner et al. 2008), whereas Thermoanaerobacter sulfurigignens (Lee et al. 2007) only produces elemental sulfur, similar to most species of Thermoanaerobacterium (Schink and Zeikus 1983; Lee et al. 1993). The ability to produce either sulfide or sulfur from thiosulfate has been proposed as a differentiating feature between the genera Thermoanaerobacter and Thermoanaerobacterium (Lee et al. 1993). However, for strain TLO we could show that the formation of hydrogen sulfide or sulfur is very much dependent on the type of medium and the $\mathrm{pH}$. At $\mathrm{pH} 6.7$ (BM-medium), sulfide was exclusively formed, whereas at $\mathrm{pH} 5.8$ (PB-medium) substantial sulfur deposition was observed. The reason for this drastic change in thiosulfate reduction is not known, but it indicates that the ability to produce either hydrogen sulfide or sulfur is not as group-specific as previously thought. 
The $\mathrm{pH}$ of the growth medium severely influenced the fermentation pattern. Whereas at basic and neutral conditions significant amounts of acetate, ethanol, and alanine were formed in addition to the major product lactate, at $\mathrm{pH}$ values between 4.5 and 5, an almost homolactic fermentation was observed. This latter feature combined with the ability to convert a wide array of substrates, and the growth on non-complex media, make this organism an interesting candidate for industrial lactic acid production.

In the absence of thiosulfate, strain TLO also produced substantial amounts of alanine $(0.3 \mathrm{~mol} / \mathrm{mol}$ glucose $)$. Alanine has been reported before as fermentation end product in sugar-fermenting thermophiles, and it is regarded as a sink for reducing equivalents (Kengen and Stams 1994; Balk et al. 2002). Accordingly, in the presence of the electron acceptor thiosulfate, alanine formation was almost negligible $(0.02 \mathrm{~mol} / \mathrm{mol}$ glucose $)$.

In the last two decades, intensive research on anaerobic, thermophilic, carbohydrate-fermenting microorganisms from marine and terrestrial volcanic hot springs has led to the isolation of several new genera and species in the domains Bacteria and Archaea. The major aim for this research stems from the biotechnological potential and the basic evolutionary traits of these microbes. CO-utilizing thermophilic microorganisms are able to grow by converting $\mathrm{CO}$ with water to $\mathrm{H}_{2}$ and $\mathrm{CO}_{2}$. This feature makes these microorganisms interesting for cost effective hydrogen production. Hydrogen gas attracts great interest as a potential clean future fuel. Besides its potential as a future energy carrier, $\mathrm{H}_{2}$ is a potent electron donor in various reductive processes, both in chemical and biotechnological applications. The use of thermophilic microorganisms for these processes could offer some advantages; although to date, few thermophiles are known that grow well on CO. The identification of new isolates that would broaden the product range of synthesis gas fermentations is desirable. Strain TLO can be one of the possible candidates for further research in this area.

In conclusion, a new thermophilic anaerobic bacterium is described that differs from its closest phylogenetic relatives, T. thermohydrosulfuricus and T. siderophilus, in the ability to use carbon monoxide, its $\mathrm{G}+\mathrm{C}$ content, and fatty acids composition. The lipid profile of strain TLO is different from $T$. thermohydrosulfuricus and T. siderophilus and characterized by the predominance of membrane-spanning lipids. Moreover, in the absence of thiosulfate strain TLO produced almost entirely lactate instead of ethanol or acetate. These differences led us to propose that strain TLO represents a subspecies of Thermoanaerobacter thermohydrosulfuricus, and we therefore name it Thermoanaerobacter thermohydrosulfuricus subsp. carboxydovorans.

The description of T. thermohydrosulfuricus is as given by Klaushofer and Parkkinen (1965) with the following modifications. Arsenate is used as electron acceptor. The most abundant fatty acids are iso- $\mathrm{C}_{15: 0}$ and iso- $\mathrm{C}_{17: 0}$ and the membrane-spanning lipids, $\alpha, \omega$-13,16-dimethyl-octacosanedioic acid, was also found. One of the subspecies of T. thermohydrosulfuricus, strain TLO, is able to grow on $\mathrm{CO}(<25 \% \mathrm{v} / \mathrm{v})$.

Acknowledgments This work was supported by the INTAS and Darwin Centre for Biogeology of Netherlands Organization for Scientific Research (NWO) and was also partly supported by Award No KUK-C1-017-12, made by King Abdullah University of Science and Technology (KAUST).

Open Access This article is distributed under the terms of the Creative Commons Attribution Noncommercial License which permits any noncommercial use, distribution, and reproduction in any medium, provided the original author(s) and source are credited.

\section{References}

Balk M, Weijma J, Stams AJM (2002) Thermotoga lettingae sp. nov., a novel thermophilic, methanol-degrading bacterium isolated from a thermophilic anaerobic reactor. Int J Syst Evol Microbiol 52:1361-1368

Balk M, Weijma J, Friedrich MW, Stams AJM (2003) Methanol utilization by a novel thermophilic homoacetogenic bacterium, Moorella mulderi sp. nov., isolated from a bioreactor. Arch Microbiol 179:315-320

Bradford MM (1976) A rapid and sensitive method for the quantitation of microgram quantities of protein utilizing the principle of protein-dye binding. Anal Biochem 72:248-254

Burdette DS, Jung SH, Shen G-J, Hollingsworth RI, Zeikus JG (2002) Physiological function of alcohol dehydrogenases and longchain $\left(\mathrm{C}_{30}\right)$ fatty acids in alcohol tolerance of Thermoanaerobacter ethanolicus. Appl Environ Microbiol 68:1914-1918

Cashion P, Holder-Franklin MA, McCully J, Franklin M (1977) A rapid method for the base ratio determination of bacterial DNA. Anal Biochem 81:461-466

Cayol J-L, Ollivier B, Patel BKC, Ravot G, Magot G, Ageron E, Grimont PAD, Garcia J-L (1995) Description of Thermoanaerobacter brockii subsp. lactiethylicus subsp. nov., isolated from a deep subsurface French oil well, a proposal to reclassify Thermoanaerobacter finii comb. nov., and an emended description of Thermoanaerobacter brockii. Int J Syst Bacteriol 45:783-789

Cook GM, Rainey FA, Patel PK, Morgan HW (1996) Characterization of a new obligately anaerobic thermophile, Thermoanaerobacter wiegelii. Int J Syst Bacteriol 46:123-127

De Ley J, Cattoir H, Reynaerts A (1970) The quantitative measurement of DNA hybridization from renaturation rates. Eur $\mathbf{J}$ Biochem 12:133-142

Escara JF, Hutton JR (1980) Thermal stability and renaturation of DNA in dimethylsulphoxide solutions: acceleration of renaturation rate. Biopolymers 19:1315-1327

Fardeau ML, Magot M, Patel BKC, Thomas P, Garcia JL, Ollivier B (2000) Thermoanaerobacter subterraneus sp. nov., a novel thermophile isolated from oilfield water. Int $\mathrm{J}$ Syst Evol Microbiol 50:2141-2149

Fardeau ML, Bonilla Salinas M, L'Haridon S, Jeanthon C, Verhe F, Cayol JL, Patel BK, Garcia JL, Ollivier B (2004) Isolation from oil reservoirs of novel thermophilic anaerobes phylogenetically related to Thermoanaerobacter subterraneus: reassignment of 
T. subterraneus, Thermoanaerobacter yonseiensis, Thermoanaerobacter tengcongensis and Carboxydibrachium pacificum to Caldanaerobacter subterraneus gen. nov., sp. nov., comb. nov. as four novel subspecies. Int J Syst Evol Microbiol 54:467-474

Gavrilov SN, Bonch-Osmolovskaya EA, Slobodkin AI (2003) Physiology of organotrophic and lithotrophic growth of the thermophilic iron-reducing bacteria Thermoterrabacterium ferrireducens and Thermoanaerobater siderophilus. Microbiology (English translation of Mikrobiologiya) 72:132-137

Henstra AM, Stams AJM (2004) Novel physiological features of Carboxydothermus hydrogenoformans and Thermoterrabacterium ferrireducens. Appl Environ Microbiol 70:7236-7240

Huss VAR, Festl H, Schleifer KH (1983) Studies on the spectrophotometric determination of DNA hybridization from renaturation rates. Syst Appl Microbiol 4:184-192

Jahnke KD (1992) Basic computer program for evaluation of spectroscopic DNA renaturation data from GILFORD System 2600 spectrometer on a PC/XT/AT type personal computer. J Microbial Methods 15:61-73

Jung SH, Zeikus JG, Hollingsworth RI (1994) A new family of very long-chain $\alpha, \omega-13,16$-dicarboxylic acids is a major structural fatty acyl component of the membrane-lipids of Thermoanerobacter ethanolicus 39e. J Lipid Res 35:1057-1065

Kengen SWM, Stams AJM (1994) Formation of $L$-alanine as a reduced end product in carbohydrate fermentation by the hyperthermophilic archaeon Pyrococcus furiosus. Arch Microbiol 161:168-175

Kim BC, Grote R, Lee DW, Antranikian G, Pyun YR (2001) Thermoanaerobacter yonseiensis sp. nov., a novel extremely thermophilic, xylose-utilizing bacterium that grows at up to $85^{\circ} \mathrm{C}$. Int J Syst Evol Microbiol 51:1539-1548

Klaushofer H, Parkkinen E (1965) Zur Frage der Bedeutung aerober und anaerober thermophiler Sporenbildner als Infektionsursache in Rübenzuckerfabriken. I. Clostridium thermohydrosulfuricum eine neue Art eines saccharoseabbauenden, thermophilen, schwefelwasserstoffbildenden Clostridiums. Z Zuckerind Boehm 15:445-449

Kozianowski G, Canganella F, Rainey FA, Hippe H, Antranikian G (1997) Purification and characterization of thermostable pectatelyases from a newly isolated thermophilic bacterium, Thermoanaerobacter italicus sp. nov. Extremophiles 1:171-182

Lane DJ (1991) 16S/23S rRNA sequencing. In: Stackebrandt E, Goodfellow M (eds) Nucleic acid techniques in bacterial systematics. Wiley, Chichester, England, pp 115-175

Larsen L, Nielsen P, Ahring BK (1997) Thermoanaerobacter mathranii sp. nov., an ethanol-producing, extremely thermophilic anaerobic bacterium from a hot spring in Iceland. Arch Microbiol 168:114-119

Lee YE, Jain MK, Lee C, Lowe SE, Zeikus JG (1993) Taxonomic distinction of saccharolytic thermophilic anaerobes: description of Thermoanaerobacterium xylanolyticum gen. nov., sp. nov., and Thermoanaerobacterium saccharolyticum gen. nov., sp. nov.; reclassification of Thermoanaerobium brockii, Clostridium thermosulfurogenes, and Clostridium thermohydrosulfuricum E100-69 as Thermoanaerobacter brockii comb. nov., Thermoanaerobacterium thermosulfurigens comb. nov., and Thermoanaerobacter thermohydrosulfuricus comb. nov., and Thermoanaerobacter thermohydrosulfuricus comb. nov., respectively; and transfer of Clostridium thermohydrosulfuricum 39E to Thermoanaerobacter ethanolicus. Int J Syst Bacteriol 43:4151

Lee S, Kang SY, Kim N, Jung SH (2002) Structural analyses of the novel phospholipids containing the unusual very long bifunctional acyl chain, $\alpha, \omega-13,16$-dimethyloctacosanedioate in Thermoanaerobacter ethanolicus. Bull Korean Chem Soc 23:1778-1784
Lee YL, Dashti M, Prange A, Rainey FA, Rohde M, Whitman WB, Wiegel J (2007) Thermoanaerobacter sulfurigignens sp. nov., an anaerobic thermophilic bacterium that reduces $1 \mathrm{M}$ thiosulfate to elemental sulfur and tolerates $90 \mathrm{mM}$ sulfite. Int J Syst Evol Microbiol 57:1429-1434

Lovley DR, Phillips EJP (1988) Novel mode of microbial energy metabolism: organic carbon oxidation coupled to dissimilatory reduction of iron or manganese. Appl Environ Microbiol $54: 1472-1480$

Ludwig W, Strunk O, Westram R, Richter L, Meier H, Yadhukumar Buchner A, Lai T, Steppi S, Jobb G, Forster W, Brettske I, Gerber S, Ginhart AW, Gross O, Grumann S, Hermann S, Jost R, Konig A, Liss T, Lussmann R, May M, Nonhoff B, Reichel B, Strehlow R, Stamatakis A, Stuckmann N, Vilbig A, Lenke M, Ludwig T, Bode A, Schleifer KH (2004) ARB: a software environment for sequence data. Nucleic Acids Res 32:1363-1371

Mesbah M, Premachandran U, Whitman W (1989) Precise measurement of the $\mathrm{G}+\mathrm{C}$ content of deoxyribonucleic acid by high performance liquid chromatography. Int J Syst Bact 39:159-167

Murray RGE, Doetsch RN, Robinow CF (1994) Determinative and cytological light microscopy. In: Gerhardt P, Murray RGE, Wood WA, Krieg NR (eds) Methods of general and molecular biology. American Society for Microbiology, Washington, DC, pp 21-41

Onyenwoke RU, Kevbrin VV, Lysenko AM, Wiegel J (2007) Thermoanaerobacter pseudethanolicus sp. nov., a thermophilic heterotrophic anaerobe from Yellowstone National Park. Int J Syst Evol Microbiol 57:2191-2193

Schink B, Zeikus JG (1983) Clostridium thermosulfurogenes sp. nov., a new thermophile that produces elemental sulphur from thiosulphate. J Gen Microbiol 129:1149-1158

Schmid U, Giesel H, Schobert M, Sahm H (1986) Thermoanaerobacter finii spec. nov., a new ethanologenic sporogenous bacterium. Syst Appl Microbiol 8:80-85

Scholten JC, Stams AJM (1995) The effect of sulfate and nitrate on methane formation in a freshwater sediment. Antonie Van Leeuwenhoek 68:309-315

Slepova TV, Sokolova TG, Lysenko AM, Tourova TP, Kolganova TV, Kamzolkina OV, Karpov GA, Bonch-Osmolovskaya EA (2006) Carboxydocella sporoproducens sp. nov., a novel anaerobic $\mathrm{CO}$-utilizing/ $\mathrm{H}_{2}$-producing thermophilic bacterium from a Kamchatka hot spring. Int J Syst Evol Microbiol 56:797

Slobodkin AI, Tourova TP, Kuznetsov BB, Kostrikina NA, Chernyh NA, Bonch-Osmolovskaya EA (1999) Thermoanaerobacter siderophilus sp. nov., a novel dissimilatory Fe(III)-reducing, anaerobic, thermophilic bacterium. Int J Syst Bacteriol 49:14711478

Sokolova TG, Gonzalez JM, Kostrikina NA, Chernyh NA, Tourova TP, Kato C, Bonch Osmolovskaya EA, Robb FT (2001) Carboxydobrachium pacificum gen. nov., sp nov., a new anaerobic, thermophilic, CO-utilizing marine bacterium from Okinawa Trough. Int J Syst Evol Microbiol 51:141-149

Sokolova TG, Kostrikina NA, Chernyh NA, Tourova TP, Kolganova TV, Bonch-Osmolovskaya EA (2002) Carboxydocella thermautotrophica gen. nov., sp. nov., a novel anaerobic, CO-utilizing thermophile from a Kamchatkan hot spring. Int J Syst Evol Microbiol 52:1961-1967

Sokolova TG, Gonzalez JM, Kostrikina NA, Chernyh NA, Slepova TV, Bonch-Osmolovskaya EA, Robb FT (2004) Thermosinus carboxydivorans gen. nov., sp. nov., a new anaerobic, thermophilic, carbon monoxide-oxidizing, hydrogenogenic bacterium from a hot pool of Yellowstone National Park. Int J Syst Evol Microbiol 54:2353-2359

Sokolova TG, Kostrikina NA, Chernyh NA, Kolganova TV, Tourova TP, Bonch-Osmolovskaya EA (2005) Thermincola carboxydiphila gen. nov., sp. nov., a novel anaerobic, carboxydotrophic, 
hydrogenogenic bacterium from a hot spring of the Kae Baikal area. Int J Syst Evol Microbiol 55:2069-2073

Sokolova T, Hanel J, Onyenwoke RU, Reysenbach AL, Banta A, Geyer R, Gonza JM, Whitman WB, Wiegel J (2007) Novel chemolithotrophic, thermophilic, anaerobic bacteria Thermolithobacter ferrireducens gen. nov., sp. nov. And Thermolithobacter carboxydivorans sp. nov. Extremophiles 11:145

Stams AJM, van Dijk JB, Dijkema C, Plugge CM (1993) Growth of syntrophic propionate-oxidizing bacteria with fumarate in the absence of methanogenic bacteria. Appl Environ Microbiol 59:1114-1119

Subbotina IV, Chernyh NA, Sokolova TG, Kublanov IV, BonchOsmolovskaya EA, Lebedinsky AV (2003) Oligonucleotide probes for the detection of representatives of the genus Thermoanaerobacter. Microbiology (English translation of Mikrobiologiya) 72:331-339

Svetlichnyi VA, Sokolova TG, Kostrikina NA, Lysenko AM (1994) Carboxydothermus restrictus sp. nov.- a new thermophilic anaerobic carboxydotrophic bacterium. Mikrobiologiya 63:523-528

Svetlitchnyi V, Peschel C, Acker G, Meyer O (2001) Two membraneassociated NiFeS-carbon monoxide dehydrogenases from the anaerobic carbon-monoxide-utilizing eubacterium Carboxydothermus hydrogenoformans. J Bacteriol 183:5134-5144

Trüper HG, Schlegel HG (1964) Sulfur metabolism in Thiorhodaceae. I. Quantitative measurements on growing cells of Chromatium okenii. Antonie Van Leeuwenhoek 30:225-238

Wagner ID, Zhao W, Zhang CL, Romanek CS, Rohde M, Wiegel J (2008) Thermoanaerobacter uzonensis sp. nov., an anaerobic thermophilic bacterium isolated from a hot spring within the Uzon Caldera, Kamchatka, Far East Russia. Int J Syst Evol Microbiol 58:2565-2573

Wiegel JG, Ljungdahl LG (1981) Thermoanaerobacter ethanolicus gen. nov., spec. nov., a new, extreme thermophilic, anaerobic bacterium. Arch Microbiol 128:343-348 